\title{
The New Perspective challenge to Luther
}

\begin{tabular}{|c|c|}
\hline \multicolumn{2}{|c|}{$\begin{array}{l}\text { Authors: } \\
\text { Bart Eriksson }{ }^{1} \text { (D) } \\
\text { Ernest van } \text { Eck }^{1}\end{array}$} \\
\hline \multicolumn{2}{|c|}{$\begin{array}{l}\text { Affiliations: } \\
\text { 1Department of New } \\
\text { Testament and Related } \\
\text { Literature, Faculty of } \\
\text { Theology and Religion, } \\
\text { University of Pretoria, } \\
\text { Pretoria, South Arica }\end{array}$} \\
\hline \multicolumn{2}{|c|}{$\begin{array}{l}\text { Research Project } \\
\text { Registration } \\
\text { Project Leader: E. van Eck } \\
\text { Project Number: } 2400030\end{array}$} \\
\hline \multicolumn{2}{|c|}{$\begin{array}{l}\text { Dr Eriksson is participating in } \\
\text { the research project } \\
\text { 'Hermeneutics and Exegesis' } \\
\text { directed by Prof. Dr Ernest } \\
\text { van Eck, Department of New } \\
\text { Testament and Related } \\
\text { Literature, Faculty of } \\
\text { Theology and Religion, } \\
\text { University of Pretoria, } \\
\text { South Africa. }\end{array}$} \\
\hline \multicolumn{2}{|c|}{$\begin{array}{l}\text { Ernest van Eck, } \\
\text { ernest.vaneck@up.ac.za }\end{array}$} \\
\hline \multicolumn{2}{|c|}{$\begin{array}{l}\text { Received: } 28 \text { Aug. } 2018 \\
\text { Accepted: } 06 \text { Feb. } 2019 \\
\text { Published: } 23 \text { Apr. } 2019\end{array}$} \\
\hline \multicolumn{2}{|c|}{$\begin{array}{l}\text { How to cite this article: } \\
\text { Eriksson, B. \& Van Eck, E., } \\
\text { 2019, 'The New Perspective } \\
\text { challenge to Luther', HTS } \\
\text { Teologiese Studies/Theological } \\
\text { Studies 75(4), a5244. https:// } \\
\text { doi.org/10.4102/hts. } \\
\text { v75i4.5244 }\end{array}$} \\
\hline \multicolumn{2}{|c|}{$\begin{array}{l}\text { Copyright: } \\
\text { (C) 2019. The Authors } \\
\text { Licensee: AOSIS. This } \\
\text { is licensed under the } \\
\text { Creative Commons } \\
\text { Attribution License. }\end{array}$} \\
\hline \multicolumn{2}{|l|}{ Read online: } \\
\hline 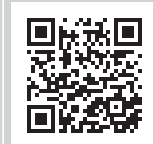 & $\begin{array}{l}\text { Scan this QR } \\
\text { code with your } \\
\text { smart phone or } \\
\text { mobile device } \\
\text { to read online. }\end{array}$ \\
\hline
\end{tabular}

New Perspective scholars challenge Protestant interpretations of Paul. It used to be the case, they state, that Protestants assumed that Paul was to Judaism as Luther was to Medieval Catholicism. Both men supposedly reacted against legalistic religions and championed gracebased faiths. However, in 1977, E.P. Sanders wrote Paul and Palestinian Judaism, arguing that Judaism is not a legalistic but a grace-based faith. Assuming that Sanders is correct, New Perspectivists claim that Paul's and Luther's theologies and experiences were thus not parallel. Hence, Luther misunderstood Paul. Additionally, New Perspectivists challenge Protestant understandings of 'justification'. In New Perspective thought, Paul uses the term 'justification' primarily to describe how people, particularly Gentiles, join the church Christians without following Jewish ritual laws. 'Justification', then, does not describe how people 'stay in' the covenant and receive salvation, as Protestants think. However, this article maintains that while New Perspectivists have some knowledge of Paul and Judaism, they are much less knowledgeable regarding Luther, Medieval Catholicism and Luther's reaction to it. Greater scrutiny of these latter areas reveals large difficulties with New Perspective arguments. In addition, a review of relevant passages from Paul's letters demonstrates that Protestants have not misunderstood Paul's use of the term 'justification'. Many Pauline passages show that when Paul discusses justification he is also thinking about 'staying in', not just 'getting in' the covenant.

Keywords: Old Perspective; Ethnicity; New Perspective on Paul; Luther; Paul; Authentic letters of Paul.

\section{Origins of the New Perspective}

For the last 500 years, many Protestants believed that Luther had correctly understood Paul. Furthermore, Protestants also assumed that both Judaism and Medieval Catholicism were legalistic faiths, where salvation was earned through good works. In contrast, Protestants believed that Christianity espoused a new covenant based on grace and faith.

As well, while Luther never claimed that his own conversion experience or the motivations for it were similar to Paul's, in recent years, some scholars, especially since the Enlightenment, have assumed that both men had similar conversion experiences; both were reacting against legalistic faiths and searching for a gracious God (Eriksson 2003a:7). In the minds of many thinkers, Paul was to Judaism what Luther was to Catholicism. Yet, within New Testament scholarship, all of this has come into question within the 20th century and especially within the last four decades.

A break with the early 20th-century Protestantism began with Wrede (1907:114) and Albert Schweitzer (1998:21). Both Wrede and Schweitzer claimed that justification was not central to Paul's thought. Instead, according to Schweitzer (1998:138), for a believer, the status of being-inChrist was all important. A few decades later, Davies (1984:138) agreed with Schweitzer's claims that Paul's theological influences were primarily Jewish rather than Greek. Furthermore, Davies (1984:136) said that Paul never left Judaism. Davies speaks about Paul receiving 'a call', rather than converting to a new faith (see Davies 1984:123).

A third major break with standard Protestant thinking occurred with Krister Stendahl. He claimed that unlike Luther, who was searching for a gracious God prior to his conversion, Paul had a robust conscience and was not driven to seek God's grace and mercy out of a dire sense of his own sinfulness (see Stendahl 1976:16). However, the real launch of this newer understanding took place in 1977, when E.P. Sanders wrote his book Paul and Palestinian Judaism. Within a few short years, N.T. Wright used the expression: 'The New Perspective on Paul', to describe those influenced by Sanders' ideas regarding Paul.

Note: HTS 75th Anniversary Maake Masango Dedication.

This article represents a reworked version of aspects from the PhD-thesis of Bart Eriksson, titled 'The new Perspective critique of Luther: A response', in the Department of New Testament and Related Literature, Faculty of Theology and Religion, University of Pretoria, with Prof. Dr. Ernest van Eck as supervisor. 


\section{New Perspective arguments}

Building on the work of Jewish scholars like Schoeps (1961) and Montefiore (1914; see also Eriksson 2003a:14), Sanders challenged the notion that Judaism was a legalistic faith. Sanders (2015:480-481) talks about Judaism's 'pattern of religion'; in other words, what it takes to 'get in' the covenant and then what it takes as well to 'stay in' the covenant. In this regard, he describes that Judaism was not legalistic but 'covenantal nomist' (Sanders 1992:262-263). By this term Sanders means that in Judaism one enters the covenant through grace (birth as a Jew and therefore a grace-based election into the covenant), but once one is in the covenant, one only needs to maintain one's covenant status by doing works (Sanders 1977:75; see also Eriksson 2003b:19). Yet, these works were not onerous because the temple's purpose was to provide atonement, offering forgiveness to those who needed it. Hence, Judaism was much more grace-based than Protestants had supposed (Sanders 1977:422).

As this is the case, Sanders asserted, Paul might not have been reacting against Jewish legalism after all. Furthermore, it would only follow that because Judaism is grace-based, we can no longer say that Paul was to Judaism what Luther was to Catholicism. Paul must have been saying something different than what Luther had assumed (Eriksson 2003c:2829). Hence, Reformation understandings of Paul need revision (Sanders 1977:431-523).

Soon after the publication of Paul and Palestinian Judaism, several individuals began exploring Paul from the starting point of grace-based Judaism. Among these, James Dunn and N.T. Wright are the best known. Wright (2013) states:

Sanders accused Protestant exegesis of retrojecting a view of 'Catholic' priestcraft, works-righteousness and so forth, onto the second-Temple period, in order that Protestantism could play the part of Luther to the faux-medieval soteriology of 'Judaism'. That is where the debate ('new perspective' versus 'old perspective') still sits. (pp. 140-141)

Although there is much diversity between New Perspective scholars (2015:64), there are some common viewpoints. Firstly, as mentioned, New Perspective scholars no longer view Judaism as a legalistic faith. Secondly, according to N.T. Wright, New Perspective scholars understand that Paul was primarily a Jewish, not a Greek thinker, and that Paul did not reject his Jewish heritage, but built on it (Wright 2013:460). Thirdly, most New Perspective scholars do not see justification as the central doctrine for Paul. Justification, in the New Perspective view, does not chiefly concern itself with eliminating sin and guilt, but rather eliminating such practices as circumcision and Jewish food laws so that Gentiles can join the church without becoming Jews. Justification thus creates unified Christian communities (Wright 2003:7). Furthermore, when Paul talks about justification, he is really discussing the process by which people, especially Gentiles, 'get into' God's covenant (Sanders 1991:544). Justification then is not about 'staying in' the covenant and entering heaven (Wright 2015:127).
Fourthly, New Perspective scholars state that Paul placed much emphasis on high moral standards for Christians (Sanders 2015:459, 630; see also Eriksson 2009:38). Segal (1990:169) and Sanders (1991:79-82) point out that Paul speaks about the law negatively when it comes to salvation and justification, but speaks positively when discussing Christian behaviour. Justification, in Sanders' understanding of Paul's thought, does not mean the imputation of fictional righteousness to otherwise sinful people. Rather, justification begins the process of real moral change in the person that will be completed at the end of all things (Sanders 1991:79-82). New Perspectivists thus criticise Protestants who deemphasise Paul's concerns about ethics and thus reduce Paul's preaching to merely eliminating a Christian's sense of guilt (Wright 2013:19).

Fifthly, as New Perspective scholars break with typical Protestant viewpoints, they are also often critical of Luther. They first fault Luther for believing that justification was chiefly about sin, guilt and ethics and not about eliminating ethnic boundaries. In addition, New Perspective scholars have suggested that Luther was in effect an antinomian, someone who minimised Paul's expectations for high standards in Christian behaviour (Eriksson 2003c:39; Sanders 1991:101). As we discussed later, closer reading of Luther reveals that this is not the case.

\section{Critique of the New Perspective views of Judaism, Medieval Catholicism and Luther}

Yet, not all modern scholars agree with the New Perspective approaches. More recently, many Jewish and Christian scholars now state that Sanders' (1992:10, 11, 91, 195, 236, 261, $262,448,450-451)$ attempts to claim that there was a 'common Judaism' are flawed and not complex enough to account for Judaism's diversity (see Brown 1966:61; Carson, O'Brien \& Seifrid 2001:505-584; Cohen 1987:135-136; Scott 1995:274276). Instead, Scott (1995:20-21, 195-196, 228, 229-231) speaks about a scholarly consensus that 1st-century Judaism was a very diverse movement. Even Dunn (2011:183) now concedes that Sanders might have overstated the elements of grace within 1st-century Judaism.

Secondly, New Perspective scholars have also misunderstood the nature of the Medieval Catholicism that the Reformers reacted against. In particular, Dunn and Suggate (1993:13, 16, 22) state that as Sanders has demonstrated that Judaism is much more grace-based than what had been perceived to be the case, we can no longer say that Paul is advocating grace in response to legalism. If Paul is not reacting to legalism, then we need to revise our grasp of Paul's true message.

Oberman (1983:194-195) studied the late Medieval Catholic nominalism that Luther reacted to. Oberman showed that Medieval Catholics believed that one entered God's covenant through grace in baptism. For them, baptism, the covenant entry point, was an unmerited act of God's grace. Yet, after 
baptism, one was supposed to maintain one's place in that covenant through works (Oberman 1983:134-135). Following from Oberman's analysis, one can see that in essence then, late Medieval nominalism is, to use Sanders' terms, a covenantal-nomist faith (Eriksson 2009:75). Its 'pattern of religion' (again using Sanders' terminology) also involves entry into the covenant through grace, but maintenance within the covenant through works. In this regard, it is more similar to Sanders' understanding of 'common Judaism' than many New Perspective scholars have realised. This discovery opens up a potential hole in the New Perspective approach. If 'covenantal nomist' Medieval Catholicism was not very grace-based (which arguably it was not), then quite possibly Sanders' depiction of a 'covenantal nomist' 1st-century Judaism would be less grace-based than what Sanders believes it to be.

Thirdly, one of the weaknesses in the New Perspective is that while Sanders, Dunn and Wright have some knowledge of Paul and 1st-century Judaism, they have much less knowledge of Luther. Direct references to Luther's writings in their works are scarce or more often non-existent. It seems that New Perspective scholars often naively assume that the positions of German 'Lutheran' scholars of the 19th and early 20th centuries are identical to Luther's. One might even say that although New Perspectivists have improved the scholarly community's understanding of Judaism, they have replaced the previous ignorance about Judaism with a corresponding ignorance about Luther and the Reformation tradition from which many of these scholars are descended.

We can briefly summarise some of the common New Perspective misunderstandings of Luther. Firstly, Luther frequently urged the performance of good works (see Luther AE 9:13-14, 16, 23, 50, 51, 58, 59, 60, 67, 72, 126, 136, 255, 272273; 22:38-39, 139-140, 146-147, 178-180; 26:310, 314-316, 343, $344,350,448$; 27:30, 80-81, 85; 28:225; 28:159; 31:84, 86, 87, 89, 358-359; 44:17-114; 45:91-92; 47:74, 103-114; 54:233; see also Plass 1959:326, 343, 355, 504, 534, 722-723, 725-726, 870, 1210, 1279, 1343, 1499-1521; Althaus 1966:251-274; Westerholm 2004:41). He merely insisted that doing these did not in any way achieve salvation. Furthermore, not only did Luther insist upon good works, at times he speaks about divine consequences that may happen if they are not performed. These consequences could include earthly discipline by God upon sinners (Luther, AE 9:255; 28:159; 31:90-92; 47:74; see also Eriksson 1995:10; Tappert 1959:344). In addition, while Luther frequently states that God freely forgives those who wish to repent, even if they stumble into the same sin frequently, he also states that for those who decide (in defiance of God's offer of grace) to not repent and deliberately persist in sin, run the risk of losing their 'saved' status and falling from grace (Luther, AE 9:197-199; 47:104-105; see also Tappert 1959:310), until at least, they decide to repent again (Luther, AE 27:80). Thus, although he does not use Sanders' terminology, one can say that Luther too has a covenantal understanding of the Christian faith, acknowledging that one must not only 'get in' but also 'stay in' God's covenant. 'Staying in' for Luther does not involve doing good works, but it does involve the willingness to repent of sin and throw oneself on God's grace, even if one's endeavours to do so are far from perfect.

Secondly, James Dunn in particular claims that Luther rediscovered that one 'got into' God's covenant through grace. Actually, the Medieval Catholics already understood this. Again, for Medieval Catholics, baptism, the covenant entry point, was an unmerited act of God's grace. The major contribution of the Reformation then was not over 'getting in' the covenant, or baptism, but over 'staying in' the covenant or as medieval thinkers termed it, the doctrine of penance (Lohse 1986:42-44). Thus, Luther's real discovery was not that one entered God's covenant through grace, rather it was that one 'stayed in' God's covenant through grace-providing one was willing to repent. This New Perspective misunderstanding has tremendous consequences for their interpretation of Luther and Paul.

In addition, Dunn (2011:179-180; 2014:222; see also Dunn \& Suggate 1993:14) frequently claims that Luther linked the motives for Paul's conversion experience with his own, although he never provides any direct reference to Luther's writings to support this. Bruce Corley (1997:10), however, has demonstrated that Luther did not compare his own conversion experience with Paul's, and Luther did not state that prior to his conversion Paul was searching for a righteous God. Hence, some of what passes today for 'Reformation' or old paradigm thinking would not in fact be supported by Luther.

Luther also would agree that the roots of Paul's thought were Jewish, more than Greek. Luther's approaches to Judaism have further been misunderstood by the New Perspective scholars. Luther understands that Judaism is more gracebased than either New Perspective or Old Perspective scholars have often realised (Gieschen 2004:144-145). Luther (AE 3:84-85; 22:338-339) frequently states that Judaism, as God intended it, was a grace-centred religion rather similar to Christianity. He believed that just as Christians are saved by grace through faith, trusting in the Messiah who has come, the Old Testament heroes were saved by grace through faith, trusting in the promise of the Messiah who (for them) was yet to come (Luther, AE 22:31-32, 70; see also Lohse 1986:340. However, he thinks that just as the Medieval Catholics misunderstood and understated the elements of grace within Christianity, many Jews did the same thing with Judaism (Luther, AE 1:249; 26:247). Hence, a grace-based faith was misunderstood to be a legalistic faith.

Furthermore, Luther understands that the Jews knew that they entered their own covenant through grace, and Luther sees the entry point, circumcision, as functioning for the Jews in the same way that Baptism functions for Christians - an indication of God's election (Luther, AE 2:44). Luther knew then that the Jews also thought that they maintained their covenant status before God through works. In this regard then, although he does not use the term 'covenantal-nomist', 
Luther would have had no problem describing Judaism, as he thinks the Jews understood it, a 'covenantal-nomist' faith. Luther believed that the Jews thought that they entered their covenant through grace, yet stayed in through works. Sanders' covenantal-nomism then would not have been much of a revelation.

Thus, when one applies greater scrutiny to New Perspective arguments, especially with regard to Judaism, Luther and Medieval Catholicism, one sees that most New Perspective critiques of Luther fall flat. Luther is not an antinomian as Sanders in effect at one point accuses him of being. Secondly, Luther also believed that Judaism, in God's original intent, was grace-based, and consequently, a grace-based approach to Judaism does not challenge Luther to the extent that many think. Thirdly, Bruce Corley has shown that Luther did not equate the motives for his own conversion with that of Paul, as James Dunn believes Luther did. Fourthly, Luther too was a sacramentalist, and as a result, the participationist focus of Schweitzer's thinking does not challenge Luther's position. Luther also believed that sinning as a matter of personal policy could result in one severing oneself from the body of Christ. As this is the case, in effect, for Luther as well, a set of ethical standards does arise from the need to remain within the body of Christ by, at the very least, consistently repenting of sin and throwing oneself on the mercy of Jesus. Fifthly, Luther understood that part of Paul's motives for writing what he wrote was to eliminate the cultural and ritual barriers between Jews and Gentiles within the church (Luther, AE 22:40). However, Luther just does not think that this was Paul's main focus.

Hence, because of these misunderstandings, many New Perspective ideas do not in fact challenge Luther's position at all. In many cases, New Perspective scholars and their forebearers are closer to Luther's positions than most of them realise. One might say Luther's own positions fall somewhere in between what has come to be known as the New and Old Perspective camps.

\section{Critique of the New Perspective approach to justification in Paul's thought}

However, it is true that, at least in one area, the New Perspective does launch a serious challenge towards Reformation thought. The challenge arises in particular when the New Perspectivists downplay the role of grace and faith at the 'staying in', point of Paul's pattern of religion (see Sanders 1977:544; 1991:58). For instance, justification, says Wright (2013:872-873,969,990), is really about covenant membership and not about salvation from sin. In short, the biggest challenge that the New Perspective offers to Protestantism is the issue of whether in Paul's thought Jesus' work on the cross atones for sins committed by Christians after baptism or are some human works or human sufferings required to supplement Jesus' atoning work.

Other scholars, like Piper (2007:118), have criticised the New Perspective diminishment of grace at the staying in point.
Piper states that this is why the title of his book, The future of Justification, has a double meaning. It is the future aspect of justification, the 'staying in' part of the covenant, which comes into question when evaluating Wright's work (2007:182-184). Is it by works or by grace (Piper 2007:111). Westerholm (2013:84) too challenges the New Perspectivist claim that Paul endorses an anticipatory justification based on faith and a final justification based on works.

However, the New Perspective scholars and their forebearers vary from each other regarding the extent to which grace is challenged in this regard. Albert Schweitzer takes the more definite position, while N.T. Wright and E.P. Sanders are more tentative and nuanced. Sanders (1992:272-275) suggests that, like the rabbis, Paul too thinks that on occasion supplemental human actions are required in order to atone for certain sins. Yet, Schweitzer goes beyond this and questions whether the atoning work of Jesus on the cross applies to post-baptismal sin among Christians at all.

Twice in his book, The mysticism of Paul the apostle, Schweitzer claims that in Paul's thought, through baptism, Christ's death atones for the sins committed by an individual prior to baptism. Yet, Schweitzer goes on to claim that in Paul's thought, sins committed after baptism are not atoned for by Christ's death. After baptism, only human suffering atones for sin (see Schweitzer 1998:220). Schweitzer (1998) writes:

According to the view of Paul ... the atoning death of Christ does not procure continuous forgiveness of sins, but only the release obtained in baptism from previously committed sins. For subsequent transgressions, atonement is secured by suffering with Christ. (pp. 146-147)

Schweitzer's Pauline interpretations are thus significantly different than those in Protestant thought. Whether he understood it or not, Schweitzer's perspectives are close to those of certain Medieval Catholic theologians. Some Medieval Catholics taught that Jesus Christ's atonement on the cross only applied to the sins covered by baptism. Baptism thus atoned for original sin and for sins committed prior to baptism, but any sins committed afterwards were cleansed either through human suffering or through works of penance. Furthermore, Luther (AE 22:333-334) was aware of similar arguments to the ones that Schweitzer proposed.

As opposed to some medieval scholars, Protestants held that the work of Jesus on the cross did atone for sins committed after baptism, as long as those sins were repented of. Yet, Schweitzer disagrees. Thus, with these statements Schweitzer challenges the central contribution of the Reformation.

Schweitzer's and Sanders' claims are not identical, but they are similar. Both propose that human suffering may atone for $\sin$. One suggests that the suffering takes place in this life, the other suggests that the suffering might take place in either this life or at least at the entrance point to the next life. As Schweitzer is so important to the New Perspective, and as these issues do present a major challenge to Reformation thought, they demand a brief review. Does Paul think that 
Jesus' atonement applies just to baptism and to the sins committed prior to it, to the 'getting in' phase of the Christian life, or does Paul also think that Jesus' atonement applies to sins committed afterwards also, to the 'staying in' phase of one's Christian experience? Are there passages that suggest that punishment from God, either in this life or at the moment of the last judgement, will atone for sin and allow us to enter eternity? If so, do these passages overthrow the Protestant paradigm?

Before we delve into the biblical texts, however, it is worth noting that the challenge that Schweitzer sets up for himself is immense. As he maintains that Christ's death on the cross does not atone for post-baptismal sin, if one finds even one clear instance in Paul where he suggests that Christ's death on the cross does in fact atone for post-baptismal sin, then Schweitzer's argument collapses. After all, Paul clearly was an original thinker. He obviously has different views of atonement than those expressed in the Old Testament or intertestamental Judaism. Although Sanders (2015:46-48) states that the rabbis might have believed in several means of atonement for sin, does Paul? After all, as Braaten (1983:6971) mentions, the New Testament embraces more otherworldly and individualistic notions of salvation than the Old Testament. As the notions of salvation and the age to come are different from the Old to the New Testaments, it would not be much of a stretch to think that concepts surrounding the atonement are different too. However, let us examine the texts.

Let us first look at passages from 1 and 2 Corinthians that might support Sanders' or Schweitzer's arguments. One of these passages is 1 Corinthians 5:5. Sanders (1992) writes:

The man who committed incest in the church at Corinth, [Paul] said, should be expelled; his body would be destroyed but his soul would be saved ( 1 Cor 5:5). This is the view that suffering and death atone, a view richly represented in second-century rabbinic literature. (pp. 416-417)

However, several problems need clarification here. Firstly, has Sanders correctly interpreted 1 Corinthians 5:5? Is this passage really talking about a situation where a man is being punished by God for his sin and that this punishment will atone for sin? Or is the passage describing a situation where Paul is requesting that the church excommunicate the individual in question, in the hopes that this will force the man to come to his senses and repent?

Paul talks about handing over the one who committed incest 'to Satan for the destruction of the flesh, so that his spirit may be saved in the day of the Lord' (1 Cor 5:5; NRSV). This could potentially support Sanders' point that there can be punishment for sins in this life. Yet, Paul's chief aim (and perhaps sole aim) with this passage instead is to talk about the excommunication of this person from the Christian community (what else would handing someone over to Satan mean?). Also, as Paul's Corinthian community would certainly not be killing or physically punishing the man, the discussion about 'the destruction of the flesh' almost certainly refers to a destruction of the man's fleshly or sinful attitude or outlook. Furthermore, one might state that 1 Corinthians 5:5 is at the very least a demand by Paul that the Corinthian church discipline the offending member. That much is clear.

The interpretation of 1 Corinthians 5:5 is also influenced by 2 Corinthians 2:5-11. In 2 Corinthians 2:5-11, Paul asks the Corinthians to forgive and restore fellowship with a repentant man that they had earlier shunned at Paul's request. If the individual in 1 Corinthians 5:5 and 2 Corinthians 2:5-11 was the same person, this suggests that Paul in 1 Corinthians 5:5 was not so much thinking that divine punishment atones for sin, but rather he was encouraging the Corinthian church to take disciplinary action. In any case, no mention of divine punishment is made in 2 Corinthians 2:5-11 regarding this man. These passages appear to be discussing disciplinary action within the Christian community, not so much atonement for sin before God.

Another passage that might support Schweitzer or Sanders is 2 Corinthians 5:10, which says:

For we must all appear before the judgment seat of Christ, so that each one may receive what is due for what he has done in the body, whether good or evil. (2 Cor 5:10; ESV)

This passage could suggest that human suffering at the last judgement at least atones for sin. However, Reformation thinkers also had a place for the last judgement in their thought. One can thus argue that the passage that we have just mentioned does not overthrow the Reformation thinking.

One of the ways the Reformers treated the last judgement can be found in Philip Melanchthon's 'Apology to the Augsburg Confession' (see Tappert 1959:133). Here he states that although entering heaven comes through the gift of grace through faith, there still is a judgement. The good works we do, says Melanchthon, will not affect our access to heaven itself, yet they will affect the kind of reward that we receive once we get there.

1 Corinthians 3:15 is another passage that possibly supports Schweitzer or Sanders. Paul writes that teachers need to be accurate in their teaching; otherwise, 'If their work is burned up ... the builder will be saved, but only as through fire' (1 Cor 3;15; NRSV). Sanders mentions this passage above as support for his arguments that human suffering at the last judgement atones for sin. Again, however, the passage is vague and difficult to interpret. 'Saved as through fire' could mean many things. Paul might be thinking of Isaiah 53:2b, which states: 'When you walk through the fire you shall not be burned, and the flame shall not consume you' (Is 53:2b; NRSV). In other words, it could mean that while others suffer God's wrath on judgement day, and while the builder's work itself might be burned up (which is itself tragic), those who are saved as through fire are spared the wrath that Paul talks about in 1 Thessalonians. The fire is going on all around the builder but he or she will manage to pass through it. 
We have looked at various passages that could support Schweitzer or Sanders. We have seen that these passages do not give clear support for their positions as they are vague and could be interpreted in several different ways. Now we will consider several passages that suggest or state outright that Jesus' death on the cross enables Christians to 'stay in' the covenant. 1 Corinthians 1:18 (ESV) says: 'The word of the cross is folly to those who are perishing, but to us who are being saved it is the power of God'. It is important to remember that Paul's audience in the Corinthians letters are baptised Christians. If Jesus' death atoned solely for prebaptismal sin, then Paul could not talk as if the benefits of the cross were a present on-going reality. Yet, he speaks about the cross as something that matters in the present tense. The work of the cross is the power of God, in the present moment, for those who are being saved.

All the sections of 1 Corinthians 15, when taken together, demonstrate that Jesus' work counts for 'staying in'. In 1 Corinthians, Paul begins by saying:

Now I would remind you, brothers, of the gospel I preached to you, which you received, in which you stand, and by which you are being saved, if you hold fast to the word I preached to you unless you believed in vain. (1 Cor 15:1-2; ESV)

In this passage, as Paul mentions 'holding fast', a present action that has future implications, Paul seems to suggest that 'being saved' is about staying in, the Corinthians' future life with God. Paul goes on:

For I delivered to you as of first importance what I also received: that Christ died for our sins in accordance with the Scriptures, that he was buried, that he was raised on the third day in accordance with the Scriptures, and that he appeared to Cephas, then to the twelve. (1 Cor 15:3-5; ESV)

This passage might only imply that Christ's death enables the Corinthians to 'get in'. Yet, if we continue, we see that his death and resurrection affects their future status with God, 'staying in'. Paul writes:

And if Christ has not been raised, then our preaching is in vain and your faith is in vain. We are even found to be misrepresenting God, because we testified about God that he raised Christ, whom he did not raise if it is true that the dead are not raised. For if the dead are not raised, not even Christ has been raised. And if Christ has not been raised, your faith is futile and you are still in your sins. Then those also who have fallen asleep in Christ have perished. If in Christ we have hope in this life only, we are of all people most to be pitied. But in fact Christ has been raised from the dead, the first fruits of those who have fallen asleep. For as by a man came death, by a man has come also the resurrection of the dead. For as in Adam all die, so also in Christ shall all be made alive. (1 Cor 15:14-22; ESV)

The term 'first fruits' in the passage is best interpreted as applying to the 'staying in' part of the covenant. In the Hebrew tradition, the first fruits are the first few bundles of grain that have become ripe. The first fruits are offered up to God in thanksgiving for the rest of the harvest that will soon ripen and resemble the first fruits. Paul uses 'first fruits' here as a metaphor to describe Jesus' resurrection. Paul also clearly states that the rest of us will end up like Jesus, the first fruits, and also be resurrected. Yet, the whole passage links our eventual 'staying in' to Jesus' death on the cross and resurrection. As 1 Corinthians 15:17a (ESV) says: 'if Christ has not been raised, your faith is futile'. The future result of the Corinthians' faith, the resurrection from the dead, 'staying in', is linked to the death and resurrection of Jesus. No mention is made of extra divine punishment or human penance necessary to bring about the forgiveness for the Corinthians' many post-baptismal sins.

Among the passages that challenge Schweitzer's view, another strong passage is 2 Corinthians 5:18-21.

\section{Paul writes:}

All this is from God, who through Christ reconciled us to himself and gave us the ministry of reconciliation; that is, in Christ God was reconciling the world to himself, not counting their trespasses against them, and entrusting to us the message of reconciliation. Therefore, we are ambassadors for Christ, God making his appeal through us. We implore you on behalf of Christ, be reconciled to God. For our sake he made him to be sin who knew no sin, so that in him we might become the righteousness of God. (2 Cor 5:18-21; ESV)

This passage again implies staying in. Once more, Paul's audience here are the Corinthian Christians, presumably already baptised. Yet, he asks them to be reconciled to God. If they need to be reconciled to God, then they need to repent of post-baptismal sin. However, in this passage, it is clearly Jesus who does the atoning work. Both before and after the passage above, Paul has been discussing the fact that Jesus was 'reconciling the world to himself' or 'being made sin so that in him we might become the righteousness of God'. Clearly, the action of reconciliation here involves the actions of Jesus. It is Jesus who is reconciling the world to himself, not humans who have to do additional works of penance in addition to Jesus' work.

There are other passages in the Corinthian letters that attach Jesus' atoning work 'staying in' as well as 'getting in'. These include places where Paul urges people to repent and commends others who do so: 2 Corinthians 2:5-11 and 2 Corinthians 7:8-13. In addition, 2 Corinthians 13:9b (ESV) states: 'Your restoration is what we pray for'. This suggests that repentance is possible. No punishment of sinners is mentioned in these passages, just repentance. We could compare these passages with Galatians 6:1, which also suggests that repentance without punishment is possible.

The case against Schweitzer is even stronger in Romans. For instance, although the meaning of Romans 7 is debated, at least two of its interpretations cause difficulty for the New Perspective. If the latter part of Romans 7 refers to Paul's own experience as a Christian, then this clearly disproves Schweitzer's notion that there is no atonement for the postbaptismal sins of Christians other than human suffering. Yet, if Romans 7 discusses the state of Paul's own mind prior to 
his conversion, then Stendahl's opinion that Paul had a robust conscience is challenged.

However, stronger counter-arguments to Schweitzer can be found elsewhere. Romans 4:22-25 (ESV) states:

That is why his faith was 'counted to him as righteousness.' But the words 'it was counted to him' were not written for his sake alone, but for ours also. It will be counted to us who believe [have faith] in him who raised from the dead Jesus our Lord, who was delivered up for our trespasses and raised for our justification.

Again, Paul's audience, the Roman church, are almost certainly all already baptised Christians. They have already 'gotten in'. Yet in this passage, Paul is talking about the future. Paul says: 'It will be counted to us'. Once more, Jesus' righteousness will be counted to those who believe or have faith. What happens in the future is 'staying in'.

For some pages, we have discussed Schweitzer's position in relation to the texts in Paul's epistles. However, if the New Perspective approach to justification by faith is to be believed, justification only refers to the 'getting in' phase of the Christian life and not to 'staying in'. Grace and faith apply chiefly to the entrance point of the covenant. Yet in the biblical passages we have just looked at, faith is seen as beneficial for something that happens in the future; 'it will be counted to us who have faith in him who raised from the dead Jesus'. Paul is saying that faith will bring about righteousness in the future for people who have already 'gotten in'. Paul then must be saying that faith helps us to 'stay in'.

Further support for the notion that Jesus' atonement applies to 'staying in' can be found in Romans 8. As mentioned, in Sanders' understanding of covenantal-nomism, one gets into the covenant through grace but one stays in the covenant through law observance. In Romans 8:4a (ESV), Paul says that Jesus came 'in order that the righteous requirement of the law might be fulfilled in us'. This would imply that Jesus' death was for post-baptismal sin also, for 'staying in', because Paul compares it to the righteous requirement of the law, which under the Jewish covenant in Sanders' understanding also refers to 'staying in'.

Once again, Sanders' understanding of covenantal nomism informs our understanding of Romans 9:30-33. Again, for Sanders, law observance is what one does as a Jew not to 'get in', but to 'stay in'. Yet in Romans 9:30-33 (ESV), Paul says:

The Gentiles who did not pursue righteousness have obtained it, that is, a righteousness that is by faith. But Israel who pursued a law that would lead to righteousness did not succeed in reaching that law. Why? Because they did not pursue it by faith, but as if it were based on works.

This again suggests that faith applies to staying in, because the parallel, 'a law that would lead to righteousness', is not about something already achieved but about something that was to be achieved in the future, 'staying in'.

In Romans 10:5 (ESV), Paul says: 'Moses writes about the righteousness that is based on the law, that the person who does the commandments shall live by them. But the righteousness based on faith says'. Again this suggests that the righteousness based on faith is about staying in, because the law passage that Paul earlier takes as parallel to it is also about staying in.

In interpreting the next passage, we need to remember that in the Greek language, the verb believe $(\pi \imath \tau \tau \varepsilon v i \varepsilon 1 \varsigma)$ is related

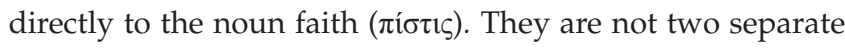
and unrelated words, as in English. As a result, when one encounters the verb 'believe', in the next few passages we could also translate it as 'have faith' or 'trust'. Romans 10:9 says: 'If you confess with your mouth that Jesus is Lord, and believe [have faith] in your heart that God raised him from the dead, you will be saved' (ESV). The same relation between faith and belief holds true in the next passage: Romans 10:11 'Everyone who believes [has faith] in him will not be put to shame' (ESV). Again, in these passages, Paul is talking about what will happen in the future, in other words 'staying in'. We see then that faith does not only apply to the 'getting in' part of the covenant in Paul's understanding, but to the 'staying in' part too. Romans 11:20 contains the same idea. Paul writes: 'They were broken off because of their unbelief but you stand fast [or remain] through faith'. Again, standing fast implies 'staying in' (ESV).

The last few passages that we have looked at relate to another argument that Wright raises to counter Stephen Westerholm. Wright (2015) states:

In his reading of 1 Thessalonians, he [Westerholm] naturally sees that 'justification' does not occur, but says that since 'justification' entails a divine initiative by which sinners meriting condemnation are reprieved and granted a place in God's 'kingdom', then the doctrine itself, though not the expression, is found there. But that is the very thing at issue: not whether Paul believed all that about the saving of sinners, but whether he used the language of 'justification' to state that point. (p. 127, [italics in original])

Wright argues that while yes, in Paul's letters 'justification' takes place through faith, Paul's use of the term 'justification' applies only to the 'getting in' aspect of the covenant and not to 'staying in'. However, in the passages above we see a link between justification and 'staying in'. In Paul's thought, 'justification' takes place by faith, but also, as we have seen above, other terms that fall under the category of 'staying in' take place by faith as well. Some of these terms Paul might refer to as 'standing fast' (Rm 11:20), 'being saved' (Rm 10:9), or 'not being put to shame' (Rm 10:11) also take place by faith.

\section{This point is further reinforced by 1 Thessalonians 5:9-10:}

For God has not destined us for wrath, but to obtain salvation through our Lord Jesus Christ, who died for us so that whether we are awake or asleep we might live with him. (ESV)

The wrath that Paul is talking about here is the wrath that happens at the last judgement, something that happens in the future. Once more, in writing 1 Thessalonians Paul is most likely speaking to a group of baptised Christians. They have 
already 'gotten in'. The future wrath that Paul says that they will avoid assures them that they will 'stay in'. Paul here refers to 'staying in' as 'salvation'. Again we see that 'salvation' or 'staying in' takes place through the work of Jesus, not through works nor through the visitation of divine punishments upon individual Christians.

In the passages above, we have seen strong support for the idea that Paul thinks that Jesus' atonement applies to the 'staying in' phase of the Christian life and not only to the 'getting in' phase. This fact makes Schweitzer's protests to the contrary seem weak. In addition, we have seen evidence that Paul thinks that a Christian's faith allows him or her to receive the effects of Jesus' atoning work in his or her life through faith. Thus, Paul speaks about faith being present to receive the effects of Jesus' atoning work, not just while 'getting in' but also while 'staying in'. Furthermore, in Paul's letters we see clear links between a variety of concepts. Being justified takes place through the work of Jesus on the cross. This act is received by Christians through their faith. At the same time, as we have seen in Romans, being saved is something that is received by Christians through their faith. 'Standing fast' also takes place by faith and 'not being put to shame' takes place by faith. In 1 Thessalonians 5 , we see a link between 'being saved' and avoiding God's wrath at the final judgement. Avoiding God's wrath at the final judgement is clearly 'staying in'. All of these concepts then are linked: faith, justification, 'staying in', standing fast in the faith, being saved and avoiding wrath. As we have seen, all of them take place through God's grace and through Jesus' atoning work on the cross. The case is thus strong for claiming that Paul saw Jesus' atoning work on the cross as applying to 'staying in' and not just 'getting in'. Hence, we can conclude that Paul saw the atoning work of Jesus as applying to postbaptismal sin, not just to pre-baptismal sin.

Before concluding this section, we should note that the New Testament authors would not have seen the effects of Jesus' work on the cross in isolation from what they presumed to be Old Testament prophecies about Jesus. One can think of several Old Testament passages that potentially foreshadow Jesus' atoning work. For instance, Genesis 22 contains the story of Abraham's near sacrifice of Isaac. During this story, Abraham continually states: 'God will provide the sacrifice'. By the end of the story, Abraham's white lie becomes true. This indicates that God, not humans, does the sacrificial atoning work.

In John 3, Jesus compares his future atoning work to the healing effect of the snake on the pole in Numbers 21. The Israelites who were healed by looking at the snake had already 'gotten in'; they were already part of the people of God. The snake on the pole rather helped remedy the poison that resulted from sins that took place after the Israelites had entered the covenant.

However, Isaiah 53 is possibly an even stronger passage than those we have already mentioned. Isaiah is the most frequently quoted Old Testament book in the New Testament. As Acts 8:30-35 illustrates, the early Christians thought that Isaiah 53 was a prophecy of Jesus' death on the cross. They would also understand that the purpose and the results of Jesus' death were described in Isaiah 53. The Messiah 'was pierced for our transgressions'. However, one has to ask, in this passage who is the prophet's audience, to whom is the word 'our' referring to? Once again, the prophet's original audience was obviously the people of Israel, people who had already 'gotten in' to the covenant. As they are already in the covenant, it is their transgressions that they have committed after 'getting in' that the Messiah's death atones for. This means that it is the transgressions at the 'staying in' not the 'getting in' phase of the people of Israel's relationship with God for which the Messiah's death atones. Certainly, this is how the passage would be understood within the early Christian community.

Finally, in terms of a parallel use of the term 'justification', it may be helpful to examine the use of this word in a passage from the Community Rule of Qumran (1QS 11:11-15, see Dunn 2011:182), which would likely have been written within a few decades of when Paul wrote his letters:

As for me, if I stumble the mercies of God shall be my eternal salvation. If I stagger because of the sin of flesh, my justification shall be by the righteousness of God which endures forever ... He will draw me near by his grace, and by his mercy will he bring my justification. He will judge me in the righteousness of his truth and in the greatness of his goodness he will pardon all my sins. Through his righteousness he will cleanse me of the uncleanness of man and the sins of the children of men. (1QS 11:11-15 in Dunn 2011:182)

In his essay in Justification: Five views, Dunn mentions that this passage demonstrates the grace-based nature of Judaism. However, what is even more interesting is the way in which the passage above treats the term 'justification'. Clearly here, 'justification' applies to sins committed after one has entered the covenant. The term 'justification' is thus used to speak not about 'getting in', but about 'staying in'.

Hence, with respect to Wright's earlier challenge to Stephen Westerholm, the selections from Paul's letters above, the Old Testament selections, and the excerpt from the writings of a Jewish sect living at the same time as Paul, all seem to indicate that the answer to Wright's question above is yes, justification is used by Paul to talk not just about 'getting in' the covenant, but also about the saving of sinners after that point.

\section{Conclusion}

Thus, in addition to the aforementioned difficulties in New Perspective arguments that arise from an imperfect understanding of Luther and Medieval Catholicism, we have also seen that Schweitzer's, Sanders' and Wright's views on the atonement can certainly be challenged. From the writings of Paul and from Old Testament sources, we have seen that the atoning work of Jesus applies not just to pre-baptismal sin but to post-baptismal sin as well.

Yet, despite the flaws in New Perspective thought, not all their contributions are wasted. New Perspective scholars 
have contributed to a better relationship between Jews and Christians. They have also rehabilitated the discussion of ethical thought within Paul's work. New Perspective scholars have contributed to the possibility of examining Paul's theology apart from the recent Enlightenment-influenced interpretations. While Luther's understandings of Paul can be defended, in certain cases the New Perspective critiques do sometimes have something to say to modern Protestantism. In any case, shedding fresh light on these topics can help bring very necessary clarity both to Paul and to the views of the Reformers.

\section{Acknowledgements Competing interests}

The authors declare that they have no financial or personal relationship(s) that may have inappropriately influenced them in writing this article.

\section{Authors' contributions}

This article represents a reworked version of aspects from the $\mathrm{PhD}$ thesis of B.E. titled 'The New Perspective critique of Luther: A response', in the Department of New Testament and Related Literature, University of Pretoria, with E.v.E. as supervisor.

\section{References}

Althaus, P., 1966, The theology of Martin Luther, transl. by R.C. Schultz, Fortress Press, Philadelphia, PA.

Braaten, C., 1983, Principles of Lutheran theology, Fortress Press, Philadelphia, PA.

Brown, R.E., 1966, The gospel according to John, Volume I, The Anchor Bible, Doubleday \& Company, Inc., New York.

Carson, D.A., O’Brien, P.T. \& Seifrid, M.A. (eds.), 2001, Justification and variegated nomism, Volume 1: The complexities of Second Temple Judaism, Baker Academic, Grand Rapids, MI.

Cohen, S.J.D., 1987, From the Maccabees to the Mishna, The Westminster Press, Philadelphia, PA.

Corley, B., 1997, 'Interpreting Paul's conversion - Then and now', in R.N. Longenecker (ed.), The road from Damascus: The impact of Paul's conversion on his life, thought, and ministry, pp. 1-17, William B. Eerdmans Publishing Co., Grand Rapids, MI.

Davies, W.D., 1984, Jewish and Pauline studies, Fortress Press, Philadelphia, PA.
Dunn, J.D.G. \& Suggate, A.M., 1993, The justice of God: A fresh look at the old doctrine of justification by faith, William B. Eerdmans Publishing Co., Grand Rapids, MI.

Dunn, J.D.G., 2011, 'New perspective view', in J.K. Beilby \& P.R. Eddy (eds.), Justification: Five views, pp. 176-201, IVP Academic, Downers Grove.

Dunn, J.D.G., 2014, 'What's right about the Old Perspective on Paul', in J.E. Smith \& M.S. Harmon (eds.), Studies in the Pauline epistles: Essays in honour of Douglas J. Moo, pp. 214-229, Zondervan, Grand Rapids, MI.

Eriksson, B., 1995, 'Luther and the third use of the Law', essay submitted for the M.Div.-programme, Waterloo Lutheran Seminary, Wilfred Laurier University.

Eriksson, B., 2003a, 'Christian scholars' attitudes towards Judaism', essay submitted for Th.M.-programme, Wycliffe College, University of Toronto.

Eriksson, B., 2003b, 'Luther, Paul and the New Perspective', essay submitted for Th.M.programme, Wycliffe College, University of Toronto.

Eriksson, B., 2003c, 'Modern interpretations of Luther', essay submitted for Th.M.programme, Wycliffe College, University of Toronto.

Eriksson, B., 2009, Luther, Paul and the New Perspective, Concordia Publishing House, Leipzig.

Gieschen, C., 2004, 'Paul and the Law: Was Luther right?', in C. Gieschen (ed.), The law in Holy Scripture, pp. 113-148, Concordia Publishing House, St. Louis, MO.

Lohse, B., 1986, Martin Luther: An introduction to his life and work, Fortress Press, Philadelphia, PA.

Montefiore, C.G., 1914, Judaism and St. Paul: Two essays, Max Goschen Ltd., London.

Oberman, H.A., 1983, The harvest of medieval theology: Gabriel Biel and late Medieval Nominalism, The Labyrinth Press, Durham.

Piper, J., 2007, The future of justification: A response to N.T. Wright, Crossway Books, Wheaton.

Plass, E.M., 1959, What Luther says: A practical in-home anthology for the active Christian, Concordia, St. Louis, MO

Sanders, E.P., 1977, Paul and Palestinian Judaism, Fortress Press, Philadelphia, PA.

Sanders, E.P., 1991, Paul, Oxford University Press, Oxford.

Sanders, E.P., 1992, Judaism: Practice and belief, 63 BCE-66 CE, Fortress Press, Minneapolis, MN.

Sanders, E.P., 2015, Paul: The apostle's life, letters and thought, Fortress Press, Minneapolis, MN.

Schoeps, H.J., 1961, Paul: The theology of the apostle in the light of Jewish religious history, Butterworth Press, London.

Schweitzer, A., 1998, The mysticism of Paul the apostle, transl. by W. Montgomery, John Hopkins University Press, Baltimore, MD.

Scott, J.J., 1995, Jewish backgrounds of the New Testament, Baker Academic, Grand Rapids, MI.

Segal, A., 1990, Paul the convert, Yale, New Haven, CT.

Stendahl, K., 1976, Paul among Jews and Gentiles, Fortress Press, Philadelphia, PA.

Tappert, T. (transl. \& ed.), 1959, The Book of Concord, 1580, Fortress Press, Philadelphia, PA.

Westerholm, S., 2004, Perspectives New and Old on Paul: The Lutheran Paul and his critics, William B. Eerdmans Publishing Co., Grand Rapids, MI.

Westerholm, S., 2013, Justification reconsidered: Rethinking a Pauline theme, William B. Eerdmans Publishing Co., Grand Rapids, MI.

Wrede, W., 1907, Paul, transl. by E. Lummis, Philip-Green, London.

Wright, N.T., 2013, Paul and the faithfulness of God, Fortress Press, Minneapolis, MN. Wright, N.T., 2015, Paul and his recent interpreters, Fortress Press, Minneapolis, MN. 